\title{
Impact of Typha Grass on Biodiversity Loss of Hadejia-Nguru Wetland Located between Jigawa and Yobe States of Nigeria: A Review
}

\author{
${ }^{*}$ ZUNGUM, IU; ${ }^{2}$ IMAM, TS; ${ }^{3}$ AHMAD, AG; ${ }^{3}$ ABUBAKAR, T; ${ }^{4}$ BENJAMIN, B; \\ ${ }^{4}$ DAYA, MG
}

\author{
${ }^{* 1,3}$ Department of Biological Sciences, Federal University Gashua, P.M.B. 1005, Yobe State, Nigeria \\ ${ }^{2}$ Department of Biological Sciences, Bayero University Kano, P.M.B. 1515, Kano State, Nigeria \\ ${ }^{4}$ Depart of Biological Sciences, Nigerian Defence Academy Kaduna, P.M.B. 2109 Kaduna State Nigeria \\ ${ }^{4}$ Department of Environmental Management and Toxicology, Federal University Dutse, P.M.B 7156 Jigawa State, Nigeria \\ *Corresponding Author Email: idzungum@gmail.com; Tel: +2348030764086
}

\begin{abstract}
Wetland - an interface between terrestrial and aquatic ecosystems are the most precious life-sustaining water resources which play crucial roles as an ecosystem service provider. This paper reviewed the impact of Typha grass on biodiversity loss of Hadejia-Nguru wetland which is located between Jigawa and Yobe State of Nigeria. Impacts exerted by Typha grass on Hadejia-Nguru wetland includes that on biodiversity; impact on birdlife; creation of microhabitats that reduces habitat for wintering of migratory and resident birds likewise provision of harbour for large flocks of Quelea birds, another invasive bird species. Typha proliferation Impacts generally, by endangering some native species towards the brink of extinction in addition, acting as trigger to decline in human socio economic activities with a resultant amplification in unemployment, poverty and crime rate. It is important that the actual biodiversity resource content of the entire Hadejia-Nguru wetland be ascertain whilst government and other stakeholders' investment of sincere commitment towards management of the menace of Typha grass be assured.
\end{abstract}

\section{DOI: https://dx.doi.org/10.4314/jasem.v23i10.13}

Copyright: Copyright $(C) 2019$ Zungum et al. This is an open access article distributed under the Creative Commons Attribution License (CCL), which permits unrestricted use, distribution, and reproduction in any medium, provided the original work is properly cited.

Dates: Received: 20 September 2019; Revised: 21October 2019; 24 October 2019

Keywords: Wetland, Typha grass, Biodiversity, Hadejia-Nguru and Ramsar site

Wetland - an interface between terrestrial and aquatic ecosystems are the most precious life-sustaining water resources and play crucial roles as ecosystem service providers and they supply food and offer a unique habitat for many different species (Debnath et al, 2018). Although wetlands occupy only two percent of the surface area of earth, they are the most productive ecosystems of the world, providing drinking water, fish, fodder, fuel, wildlife habitat. it plays vital role in global cycling of nutrients, thus, a potential source of carbon sequestration, regulate groundwater replenishments by quality and quantity of water table, stabilize and protect shorelines from the devastating effects of natural calamities such as hurricanes, cyclones and tsunamis (Debnath et al, 2018). According to (Goutam, 2016) wetland additionally, perform an important part in the sustenance of different life forms and overall a safe and resourceful reservoir of biodiversity and often harbors many endemic as well as endangered species. Wetlands also offer a welcome pit-stop; provide protection and food before the migratory birds on their way to their final destinations and equally, it provides livelihood for numerous people living around them. Many species of wetland flora and fauna are often harvested by the local communities for personal and commercial use (Goutam, 2016). Apart from the well-known benefits of wetlands to man which is the provision of avenue for fishing, farming, irrigation and provision of numerous recreational opportunities, other benefits derived from wetlands include helping to control flooding and storm water, protecting water quality by filtering and breaking down sediments, nutrients, toxins and, treating pollution by serving as a biological and biochemical oxidation basin. Control of erosion by serving as a sedimentation area and filtering basin for slit and organic matter as well as providing water shade is another task it supplies (Babagana et al., 2018a). Wetland ecosystems are globally being altered and reduced at an alarming rate by human and human induced activities. These are happening at the detriment of wetland hydrology and its biodiversity to which Hadejia-Nguru is not an exception (Babagana et al., 2018a).

Biodiversity encompasses the grand total of all the different life forms of our planet (Debnath et al, 2018). Unfortunately, despite the value of wetland 
biodiversity and the influence of some wetland attributes on species diversity, wetlands are still declining locally and regionally as a result of human and human induced pressure (Parra et al., 1989).Bioinvasion is of topical significance due to its frequent occurrence nowadays, covering every continent and island that continues to alter and degrade natural wetlands (Hager, 2004; van der Velde et al., 2006). They have been considered second major threat to biodiversity following habitat destruction (Elizabeth and Scott, 2000). Wetland invasive species share common traits such as rapid dispersal and regeneration, ability to form dense monoculture stand, and usually have an ability to regenerate profusely from direct seeds, stems or roots (Ringim et al., 2016). Furthermore, other undesired effect associated with invasive species is financial implications involved in their eradication and monitoring (Babagana et al., 2018a). On continental scale, the United Nation Environmental Programme (UNEP) estimated that alien invasive species cost the global economy an annual \$1.4 trillion (Obiri, 2011). In Nigeria, the annual costs estimate for invasive species is about $\$ 50$ million (Kasulo, 2000). In East Africa, the World Bank/GIF Lake Victoria Environmental Management Project allocated \$6-10 million to control Water hyacinth (Eichornia crassipes) per annum (Kasulo, 2000). Wetlands are susceptible to biological invasion as a result of natural and human induced influence which makes many species to invade new regions at an unprecedented rate and exerting strong impacts on ecosystems and human welfare (Van Kleunen et al., 2010). Typha grass (Typha spp.) is an invasive species also known as cattail, is a plant locally referred to as Kachalla by the people living around Hadejia-Nguru wetland area of North-Eastern Nigeria, Jigawa and Yobe States (Akinsola, 2000). The Typha family, represented worldwide by genus Typha and the weed is a perennial aquatic herb with cosmopolitan distribution in freshwater habitat, it is an erect perennial and can grow two or more meters in height (Bender, 2018). The Typha family has higher growth rate than any other aquatic plant and the family, is characterized by having rhizomes, extensive fleshy stems, tall, leaf blades, strap-like, stifle, spiraling in top half, sheathed together at base flattened (Yakubu et al., 2015). The weed is inflorescence spike like, densely packed with tiny male flowers in top cluster, and female flowers in bottom cluster. The fruits are hairy and about 5-8mm long (Yerima, 2016).

Hadejia-Nguru Wetlands which lies along a central coordinates of Longitude $10^{\circ} 33^{\prime}$ East and Latitude $12^{\circ}$ $39^{\prime}$ North, with altitude of $152-305 \mathrm{~m}$, It is an extensive area of floodplain located in the northeastern Sudano-Sahelian zone of Nigeria, covering an area of approximately 3,500 square kilometers and it has an annual rainfall which ranges between $200-600 \mathrm{~mm}$, with a rainy season that lasts three to four months, confined to the period late May-September (Ringim et al., 2016). It receives water from Hadejia and Jama'are rivers which drains into Lake Chad. The former rises in the hills around Kano while the latter rises in the Jos Plateau and they join within the Hadejia-Nguru Wetland to form the Yobe River, which discharges into Lake Chad (Sulaiman et al., 2014). The wetlands are notably known for recharge and replenishment of underground water in the Komadugu-Yobe Basin, it is an ecological and economically rich habitat for biodiversity of various fauna and flora. The area is a major tourism location for the Palaearctic and Afrotropical migrant water birds (Olalekan et al., 2014).

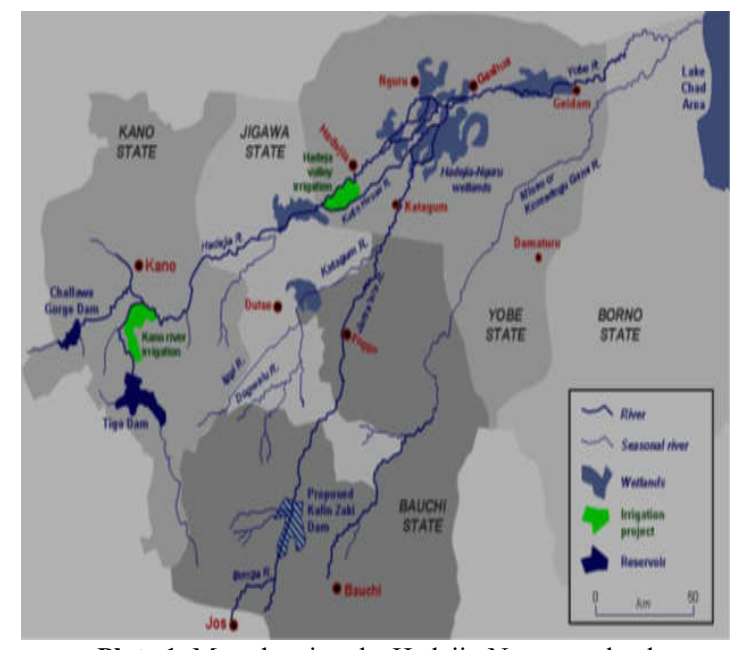

Plate 1: Map showing the Hadejia-Nguru wetland

The Hadejia-Nguru wetland is the first Nigerian wetland to be named a Ramsar site (Ramsar, 1994). From the foregoing, it becomes imperative to review extend to which the typha grass proliferation affects biodiversity, socio economic activities and public wellbeing of the area. The objectives of the study therefore, are to review the Impact on; Bird life, Vegetation, Hydrology,Invertebrates, Farming, Grazing, irrigation and Fishing Activities, Livelihood and Public Health.

Impact on bird life: The Hadejia-Nguru wetlands being a Ramsar site is nationally and internationally renowned for its ornithological importance as it supports large population of both resident and migratory species from Palearctic and Afro-tropical regions. However, over the years, Typha grass create microhabitats reducing critical habitats for feeding, nesting and roosting habitat for birds, as well as hampers the smooth flow of water which flood and 
degrade wetlands used by many water birds species (Sulaiman et al., 2014).Thereby, displacing some wetlands birds around the area (Sabo et al., 2016), it also provides a harbor for large flocks of Quelea birds (another invasive bird species in the basin), which are cereal crops pests (BirdLife International, 2016). As mentioned by Birdlife international, (2010), at one time the area covered by Typha grass increased from 550 ha to over $200 \mathrm{~km}^{2}$ in five years, this have a great effect on the structure of birds community (Verma et al., 2004, Reginald et al., 2007). Because factors such as vegetation structure, wetlands size, and substrate, plays an important role in influencing birds diversity and abundance in wetlands (Birdlife International, 2016). Therefore, dense biomass of Typha grass may reduce bird's diversity and density, more especially waterfowl which prefer open water to swim and feed. Water birds diversity and density has been thought to decrease in Nguru Lake and Marma Channel due to dense biomass of Typha grass but also, decreases in migratory species in the wetlands have also been attributed to decrease in the wetlands size (Kutama et al., 2016). Vegetation such as Acacia spp. are threatened due to the Typha invasion and are important roosting sites for the vulnerable European turtle dove (Ringim et al., 2017).

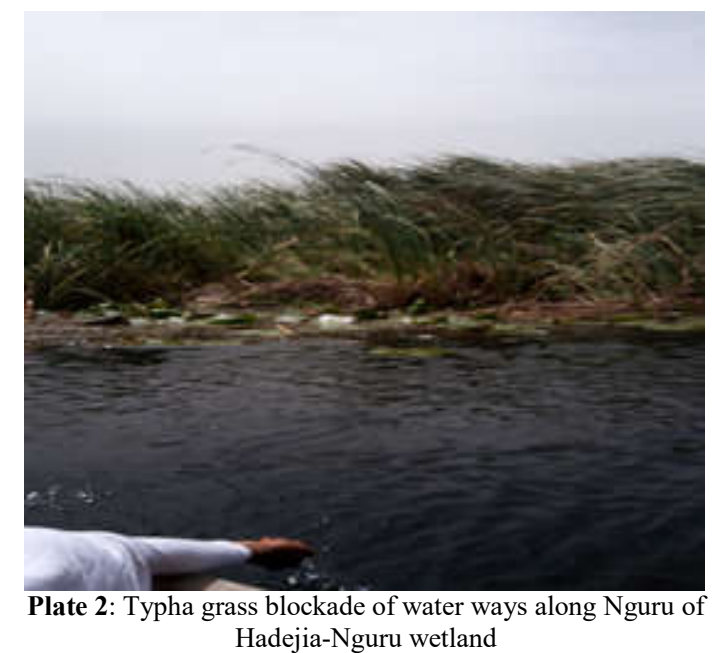

Impact on Vegetation:Invasive species may alter community structure through exploitation competition (indirect interactions such as resource use), and interference competition (direct interactions such as allelopathy in plants, as well as plant succession (Charles and Dukes, 2007). According to (Abubakar, 2012), aquatic macrophytes such as Typha grass present in dense biomass have the ability to influence plant structure and distribution and also, extensive litter deposition by Typha grass also buried mineralized substrates necessary for many native plant to germinate (Hager, 2004; Lynn, 2005). This may strongly affects plant community composition by inhibiting their establishments that may lead to habitat homogenization (Charles and Dukes, 2007). Consequently, this may decline the abundance of economically valuable species, in particular those used for food, fodder and/or medicinal plants and loss of local genetic resources thus, genetic diversity (Lynn, 2005). More so, primary production may increase or decrease if plant invader leads to a shift in the major vegetation type of a wetlands area (Ringim et al., 2017). However, most invasive plants increase net primary productivity as in the case with giant reed (Arundo donax), and other Typha spp. such as Phragmites in marshes (Ehrenfeld, 2003). In Tukwikwi flood area of the Hadejia-Nguru wetland, about $70 \%$ of the wetland was covered by both Typha and Daura grasses (Yakubu, 2015).

Typha grass has reached secondary succession covering the entire wetland as far as $2 \mathrm{~km}$ on both sides of the road and more than $20 \mathrm{~km}$ along the road from Hadejia to Nguru, consequently, hindering farming and fishing activities (Kutama et al., 2016). The invasion of Typha grass has led to the vulnerability and endangering of some native vegetation such as Acacia spp.(Ringim et al., 2017).

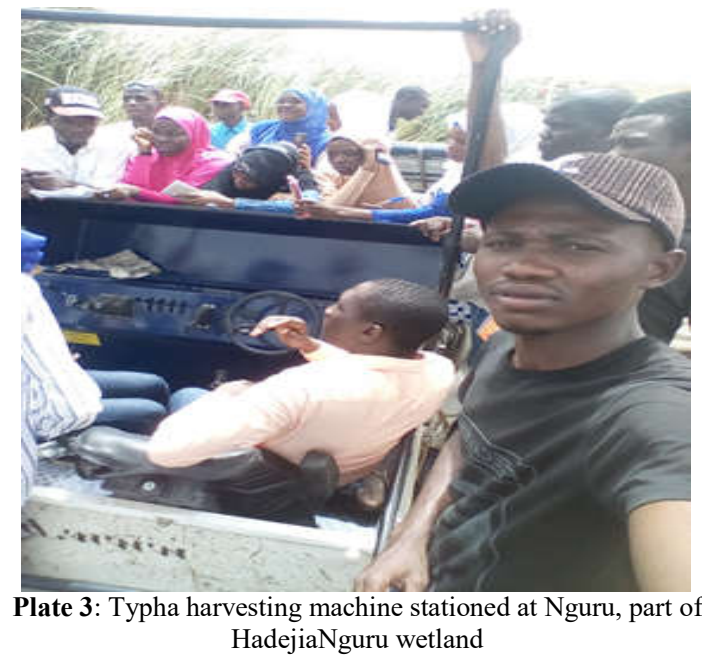

Impact on Hydrology:It also alters the biodiversity of aquatic ecosystems as well as reduction in light penetration within the aquatic system and in 2002 the National Institute for Freshwater Fisheries Research (NIFFR) revealed that, this plant was responsible for the above problems in Hadejia. Typha grass proliferation could degrade and deteriorate water quality resulting in reduce dissolved oxygen concentration level, and consequently impose stress on the survival of aquatic animals (Thompson, 2010). 


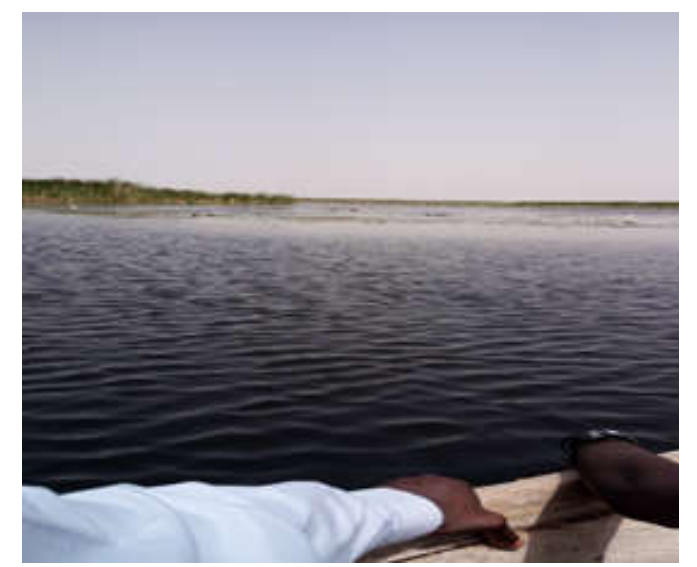

Plate 4:Hadejia-Nguru wetland an open waters along KakoriNguru

Impact on Invertebrates:Impacts of biological invasions can be found on all levels of the ecological organization that is; individuals, populations, species, communities and ecosystem. Specifically, dramatic changes can occur when introduced species function as keystone species or ecosystem engineers thus, affecting the functional diversity and food web structure of communities and ecosystems (van der Velde et al., 2006). Dense stand of Typha grass has shown to reduce upwelling of nutrients making them less available to phytoplankton in the photic zone as well as reduction in zooplankton feeding rates as vegetation become dense (Abubakar, 2012). For instance, aquatic plants such as water hyacinth (Eichornia crassipes) that form floating mats can decrease macro invertebrate abundance by blocking light transmission and decreasing photosynthesis by phytoplankton and other plants, thereby leading to anoxic conditions (Masifwaet al., 2001). Moreover, copious deposit of litter produced by Typha grass affects water quality, increased turbidity that affect phytoplankton community through their inability to photosynthesis which in turn affect zooplanktons diversity and abundance (Abubakar, 2012).

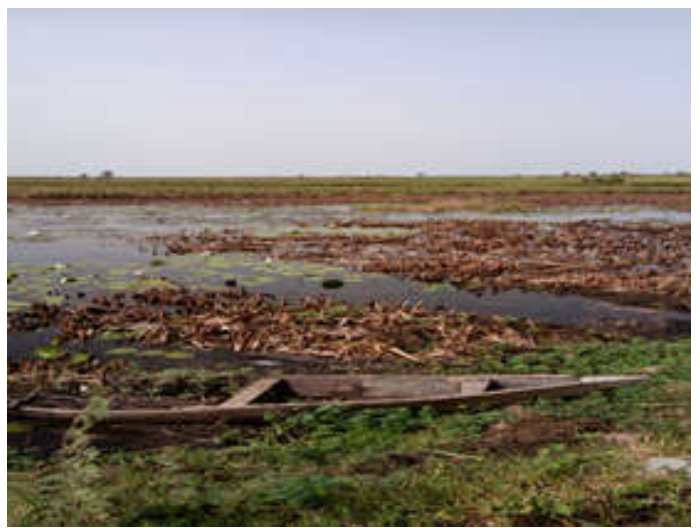

Plate 5: Remain of removed Typha grass along Hadejia-Nguru wetlands at Nguru
Impact on Farming, Grazing and irrigation:On the Marma channel and Nguru lake (a section of HadejiaNguru wetlands) for an example, where Typha invasion is more severe with over 35,000 hectares of potential farming and grazing lands have been taken over by the Typha grass., conversely, it has also contributed to the desiccation of BurumGana channel, where about $60 \%$ of dry season irrigation farms have been hindered. The studies by (Yerima, 2016), revealed that the economy and ecology of the people living in Hadejia-Nguru wetland is threatened with proliferation of an invasive Typha grass which is colonizing most irrigated lands and the People in the area are currently living within the poverty scale. Because, the presence of the weed in the area has markedly interfered with the utilization of water and land resources, this weed inhibits agricultural activities which are the primary occupation of the inhabitants. Consequently, there is loss of farm lands, fishes, hunting as well as grazing lands (Yerima, 2016). In the same vein, results of the study conducted by (Babagana et al., 2018)a revealed that hunting has reduced by $66.7 \%$ and $80 \%$ of the main canal and other water distributaries channels have been overtaken by Typha grass thereby blocking the free flow of water into the irrigation fields (Babagana et al., 2018b).

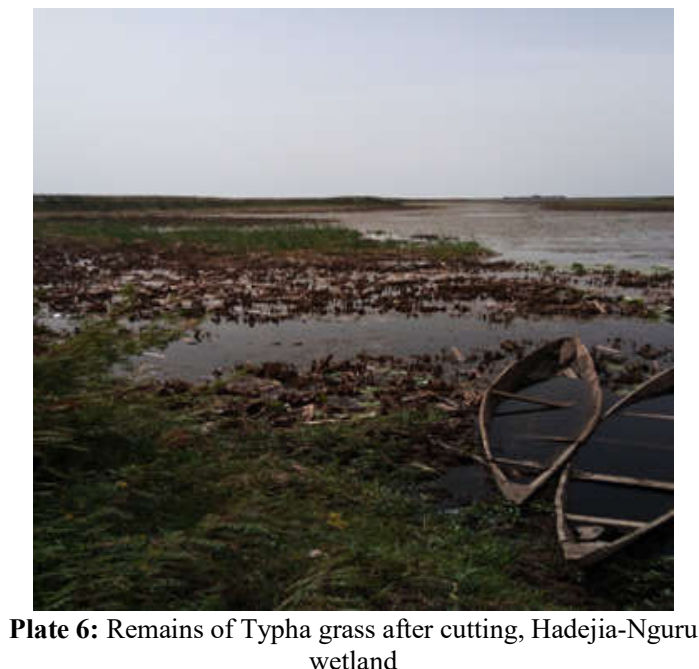

Impact on Fishing Activities: According to Kutama et al., (2016), large biomass of Typha grass has been responsible for the decline in fish catch, diversity, as well as size and abundance presumably that Typha grass vegetation provide a hiding ground for many fish species with African Arowana (Heterotis niloticus) being a typical example. Channel blockages caused by Typha grass have reduced flooding in many parts of the wetlands that lead to decrease in fish abundance (Ringim et al., 2016). Similarly, (JEWEL project, 2004) reported that the average income of fish catch 
per fishermen has reduced from about $\$ 5$ per day to less than $\$ 3$ per day (Sabo et al., 2010).

Impact on Livelihood: Typha grass has become a nuisance affecting social and economic well-being of the people that depend solemnly on the wetland for their livelihood. The major environmental impact of weed infestation is the blockage. In some instances even diversion of channels. This has led to parallel incidences of channel desiccation and inundation in the Hadejia-Nguru wetlands, the net consequences of which have been loss of livelihood, poverty and resources use conflicts (Lameed, 2011). Typha grass decreases incomes, hence, increases poverty level of communities around the wetlands and also often lead to conflicts among farmers (Babagana et al., 2018a). The invasive plant has colonized many large farms and grazing lands and river channel thereby making life miserable for the inhabitants through interference with their utilization of water and land resources. This led to migration of the inhabitants from one area to another causing conflict over resource use, and increased poverty (Sulaiman et al, 2016). Transportation, hunting and tourists guiding were successful economic activities engaged by local communities along the Nguru wetlands. Although, according to the local community dwellers, the menace of Typha grass invasion in recent years had badly affected these professions, few people still manage to survive on them and transportation activities using means such as canoes, vehicles, motorcycles, carts and wheel barrows still serve as sources of livelihoods to few people in the area but generally at the verge of coming to an end. Equally, (Babagana et al., 2018b; Kutama et al 2016) reported that Maikintari flood along Hadejia-Nguru road, the wetland was an entirely different thing as it was $100 \%$ occupied or dominated by Typha grass. One could not see any water/wetland at a glance from or by the road side. Typha grasshas become a serious menace to several human activities in the Hadejia-Nguru wetland (Babagana et al., 2018b).Typha grass harbours thieves and other criminals especially cattle rustlers and Kidnappers (Haladu and Bello, 2014). According to Ringim et al., (2016) impacts of Typha grass on recreation and tourism, boating, swimming and diving activities are enormous some years back but are no longer in practice lately (Babagana et al., 2018a).Public Health Impact: Typha grass serves as host to the vectors of Cholera, Bilharzias (Schistosomiasis), Malaria and Dysentery (Gabriel et al., 2016). The prevalence of Mosquitoes and related diseases are on the increase due to Typha takeover of the wetland and according to (Gabriel et al., 2016). Malaria was perhaps, the most prevalent disease affecting the communities dwelling around Hadejia-
Nguru wetland because it was ideal for mosquitoes breeding as long as the area was not completely deoxygenated by aquatic plants and the possible explanation for this is that Typha grass provides a good habitat for the laying and hatching of mosquito eggs as it shelters it against high isolation and wind.

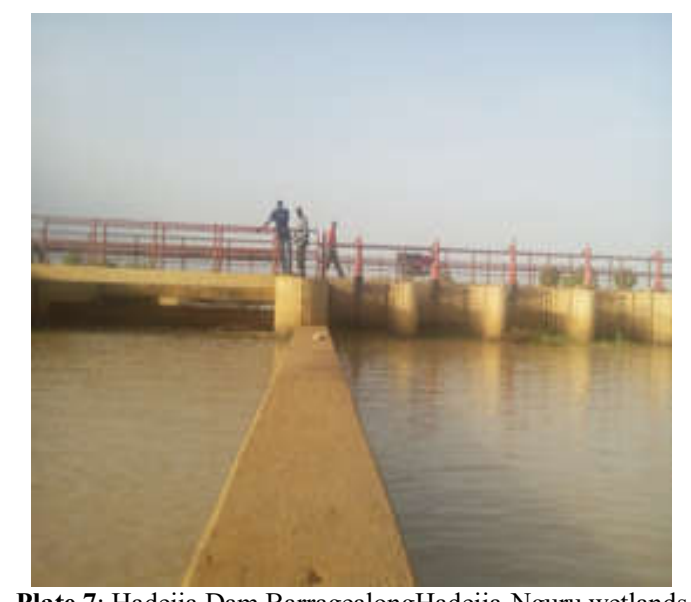

Plate 7: Hadejia Dam BarragealongHadeija-Nguru wetlands

Conclusion: Typha grass proliferation is in defiance to the much publicized efforts devoted by government and other related stakeholders such as the HadejiaNguru wetlands Conservation Project (HNWCP), Nigeria Conservation Foundation (NCF) and KomodouguYobe Basin Wetlands Development Initiative (KYB-WDI). A way forward however, for effective management of these challenges: the stakeholders needs to prioritize involvement with sincerity while partnering with relevant professionals to tackle the menace. It is therefore, recommended that (i) Persistence of the menace of typha grass proliferation necessitates adoption and application of appropriate techniques for each section of the wetland to minimize incurring further damage to the wetland units. In addition, it is crucial that investigation of the extent to which other biodiversity units such as reptiles, amphibians, and insects within the HadaijaNguru wetland are impacted. (ii) Government in Nigeria and other stakeholders should collaborate to establish a processing,conversion and fodder production plants for translation of the weed to positive utility such as; fuel pellet, building materials, fodder for animals, furniture, roof thatching etc. The processing plants are required to be sited within reach of the impacted communities, to curb unemployment induced by Typha grass proliferation. (iii) Consistent financial means needs to be sought through NEPAD, NEEDS, SEEDS, NGO's or by any other means necessary to fund research activities and adopted control technologies for the Typha grass management with the involvement of the immediate communities affected (iv) Raw Material Research and Development 
Council, Abuja, is currently developing a technology to briquette the Typha grass of the Hadejia-Nguru wetlands. Under this project, the Typha grass in Hadejia-Nguru, will be briquetted into fuel pellets for local utilization and for export using technology from neighboring Mali. Stakeholders need to follow up this agency to see to it, that the project translates to reality and (v) Biological control: equilibrium point can be attained by identifying and introducing the natural prey of typha grass to maintain its population at a stage of negligible harm.

\section{REFERENCE}

Abubakar, MM (2012). Impact of Emergent Macrophytes on Fish Catch in Nguru Lake. Bay. J. of Pur. and Appl. Sci. 5(2): 47-50.

Babagana , M; Adamu, A; Usman, DD; Amma, HA; Ado, G; Yakubu M; Zungum, IU (2018a). Characteristics and Socio Economic Activities of Local Communities Living Along the Nguru Wetlands, Yobe State, Nigeria. Int. J. of Contemp. Rese. and Rev.9(6),ISSN 0976 - 4852.

Babagana, M; Mbatudde, M; Abubakar, A; Yusuf, AM; Gambo, SS (2018b). Typha grass (Typhadomingensis) and its Control Strategies AlongNguruWetlands, Yobe State, Nigeria. Int. J. of Agric. Enviro. andBiorese.3(2), ISSN: 2456-8643

Bani, G (2002). Status and management of Chromolaenao dorata in Congo In: Zachariades C, Muniappan R, Strathie LW (eds). Proceedings of the Fifth International Workshop on Biologicals Control and Management of Chromolaenaodorata, Durban, South Africa, October 2000, 34Pietermaritzburg, pp 34-39

Bender, DA;Bender, AE (2018). A Dictionary of Food and Nutrition, Third Edition. New York: Oxford Reference Collection. 9780198829003.

BirdLife International (2016a).International Union for the Conservation of Nature Red List for birds. Downloaded from http://www.birdlife.org on 05/02/2016.

Birdlife International (2010). In Nigeria, the Birdlife Partner is assisting Wetland Restoration to Safeguard Ecosystem Services. Presented as part of the BirdLife State of the World's Birds, Retrieved from:http://www.birdlife.org/datazone/sowb/casest $\underline{\mathrm{udy} / 36}$

Charles, H; Dukes, J. S. (2007). Impacts of Invasive Species on Ecosystem Services. In Biological invasions ( $p$ p 217-237)", Springer Berlin Heidelberg.
Debnath, P; Ambarish M; Santanu G (2018). Bioresources and Socio-economic Developmental Plans (SDPs) in Wetland Ecosystem: A Case Study. In Goutam Kumar Saha. Wetland Crisis and Options: Published by Associated Publishing Company, A Division of Astral International Pvt. Ltd. - ISO 9001:2008 Certified Company retrieved from www.astralint.com

Ehrenfeld, JG (2003). Effects of Exotic Plant Invasions on Soil Nutrient Cycling Processes. Ecosystems. 6:503-523.

Elizabeth, EL; Scott, EM (2000). Invasive Species in East Africa: Proceedings of a workshop held at ICIPE, July 5-6, Conference of the parties to the Convention on Biological Diversity, fifth meeting, Nairobi, Kenya. Retrieved from https://www.cbd.int/doc/meetings/cop/cop05/information/cop-05-inf33-en.pdf

Gabriel, S; Henry, S; Oluwasogo, O (2016). Does Typha spp. contribute to Wetland Water loss and Health Risk: A Case Study of HadejiaNguru Wetlands (HNW) System, North EasternNigeria.Op. J. of Eco. 151-158.

Goutam, KS (2016). Wetland Crisis and Options. Published by Associated Publishing Company, A Division of Astral International Pvt. Ltd. - ISO 9001:2008 Certified Company retrieved from https://www.researchgate.net/publication/32559723 6 Wetland Crisis and book Chapter · June 2018.

Hager, HA (2004). Differential Effects of Typha Litter and Plants on InvasiveLythrumsa licaria Seedling Survival and Growth. Bio. Invas.,6(4): 433-444.

Haladu, HK; Bello, AA (2014). Prospect and Challenges of Farming along the HadejiaNguru Wetland in Jigawa State Nigeria. Intern. Joun. of Acad. Res. in Econ. and Man.Sci. 3(6),: 2226-3624

Kasulo, V (2000). The Impact of Invasive Species in Africa Lakes: The Economics of Biological Invasions. Edward Edgar Publishing, pp.183.

Kutama, AS; Abubakar, MM; Suleiman, IM; Kabir, S (2016). Flowering Plants Biodiversity in HadejiaNguru Wetlands, Nigeria. Glo. Adv. Rese. J. of Agri. Sci. 5(3) pp. 121-125

Lameed, F (2011). Species diversity and abundance of wild birds in Dagona-Waterfowl Sanctuary Borno State, Nigeria.Afri. J. of Enviro. Sci. and Tech. 5: $855-866$

Lynn, EV (2005). Patterns, Mechanisms, and Ecological Implications of Cattail (Typha spp.) Dominance in 
Great Lakes Wetlands, New York, USA, M.Sc thesis, University of Cornell, pp 6-50

Masifwa, WF; Twongo, T; Denny, P; (2001). The Impact of Water Hyacinth, (Eichorniacrassipes) (Mart) Solms on the Abundance and Diversity of Aquatic Macro invertebrates along the Shores of Northern Lake Victoria, Uganda. Hydrobio. 452(1-3): 79- 88.

NIFFR, (2002). National Surveys of infestation of water hyacinth, Typha spp. and other noxious weeds in water bodies of Nigeria. pp21-32

Obiri, FO (2011). Invasive Plant Species and their Disaster Effects in Dry Tropical Forests and Rangelands of Kenya and Tanzania. J. of Disas. and Risk Stu. 2: 417- 428.

Parra, O; Jara, C; Guzmán, L (1989). Las lagunas interurbanas de Concepción: Estado actualyperspectivas de recuperación y uso. CIPMA. Concepción, Chile

Ramsar,(1994). Convention on Wetlands of International Importance Especially as Waterfowl Habitat,United Nations Educational, Scientific and Cultural Organization (UNESCO): Paris, France.

Ringim, AS; Dogara, MM (2017). A Survey of Avifauna and Vegetation Communities in Hadejia-Nguru wetlands, Nigeria. Bayero J. of Pu. and Appl. Sci., 10(2):1-10, ISSN 2006 - 6996

Ringim, AS; Sabo, BB; Harry, H (2016). Implication of Invasive Plant Typha spp. on Biodiversity: An Ecological Study of the Hadejia-Nguru Wetlands, Nigeria. Sch. J. of Bio. Sci.4(5), 40-46

Ringim, AS; Abubakar, MM; Mohammed, SI; Shuaibu, $T$ (2015). Wetlands Resource Use, Conflict, Management and Conservation: Review of the Hadejia-Nguru wetlands, Northeast, Nigeria. Int. J. of Innov. inSci, Engin. and Tech. 2(10): 507- 516.

Reginald, LJ; Mahendran, C; Kumar, SS; Pramod, P (2007). Birds of Singanallur Lake, Coimbture, Tamilnadu. Jour. of Zoos, p22 : 2944-2948.

Sabo, BB; Maigari, AI (2016). Birds Diversity and their Relationship with Typhagrassin Hadejia-Nguru Wetlands. Int. J. of Appl. Rese. and Tech. ISSN 2277-0585

Sabo, BB; Karaye, AK; Badamasi, MM (2010). Typha Grass Militating against Agricultural Productivity along Hadejia, Jigawa State, Nigeria. Proceedings of the $21^{\text {st }}$ Annual National Conference of Farm Management Association of Nigeria, 11th 14thOctober 2010.Pp 234-254
Sulaiman, IM; Abubakar, MM; Ringim, AS; Apeverga, PT; Dikwa, MA (2015). Effects of wetlands type and size on bird diversity and abundance at the HadejiaNguru Wetlands, Nigeria. In $t$. J. of R e s e. Stu. in Zoo. 1(1), 15-21.

Sulaiman, IM; Cresswell, W; Dami, FD (2014). Bird diversity and abundance in relation to typhaoccurance at the Hadejia -Nguruwetlands. Biotrop. Rese. Int. j. 6 (1) 2141-0410.

Thompson, JR; Polet, G (2000) Hydrology and land use in a sahelian floodplain wetland. Wetlands, 20: 639659.

United Nation Office for Project Services (UNOPS) (2014). Demonstration Project Document-Wings Over Wetlands, wow. wetlands.org/Portals/1/.../demo_project_ document_

Van der Velde, G; Rajagopal, S; Kuyper-Kollenaar, M; Bij de Vaate, A; Thieltges, DW; MacIsaac, HJ (2006). Biological Invasions: Concepts to Understand and Predict a Global Threat, In: Bobbink, RB; Beltman, B; Verhoeven, JTA; Whigham, DF. Ed. Wetlands: Functioning, Biodiversity Conservation, and Restoration, vol. I. Springer Berlin Heidelberg New York, p61-63.

Van Kleunen, M; Weber, E; Fisher, M (2010). A MetaAnalysis of Trait Diffeences between Invasive and Non-invasive Plant Species. Ecol. Lett. 13(2): 235245.

Verma, A; Balachandran, S; Chaturvedi, N; Patil, V (2004).A preliminary survey on the Biodiversity of Mahul Creek, Mumbai, India. J. Zoos. p19: 15991605. 217.

Yakubu, BA (2015). Studies on the ecology and control of Typhaspp. in Hadejia-Nguru wetlands, Nigeria.A doctor of philosophy $(\mathrm{PhD})$ Dissertation in Botany submitted to Ahmadu Bello University, Zaria. P 6-8.

Yerima, M (2016). Analysis of the effects of Typha grass infestation on the livelihood of the farmers living within Hadejia-Nguru conservation project. A doctor of philosophy $(\mathrm{PhD})$ Dissertation degree in agricultural extension and rural sociology submitted to Ahmadu Bello University, Zaria. p.10-21. 